\title{
NÃO TER POSIÇÃO MARCADA: \\ ANA C. NOS ANOS 70
}

\author{
Luciana Di Leone
}

lulidileone@yahoo.com.ar

Percorrendo a historiografia literária das últimas décadas, sabemos que a geração de poetas que começara a produzir nos primeiros anos da década de 1970, tem sido - sob diferentes nomes (geração mimeógrafo, geração marginal, poesia 70) - abundantemente estudada. Mas são dois os textos ainda paradigmáticos: o prefácio à antologia 26 poetas hoje de Heloisa Buarque de Hollanda (1976), e Retrato de época (1981) de Carlos Alberto Messeder Pereira. Esses textos, feitos numa mistura de calor da hora e tentativa de caracterização mais rigorosa, por pessoas que de uma forma ou outra também participavam dessa produção e tinham um alto grau de envolvimento como colegas ou professores dos poetas, foram muito determinantes do olhar crítico articulado sobre a produção daqueles anos, havendo até hoje poucos estudos de releitura da época que fujam desses parâmetros ou os revisitem.

O presente artigo não pretende traçar um retrato - nem um "outro retrato" - da época, mas revisitar essas leituras fundadoras buscando analisar o lugar (singular, porém não excepcional como costuma apontar-se) que Ana Cristina César procurou nesse campo literário que passava, no momento em que ela começa a escrever, por uma intensa redefinição, em um contexto político de gradual distensão. Isso implica 
levar em conta um dado "objetivo" e particular poucas vezes destacado: ela começara a publicar seus artigos no final de 1975 e seus poemas em 1976, ${ }^{1}$ cinco significativos anos após as primeiras expressões da poesia dita marginal, mas simultaneamente às primeiras publicações desses poetas por grandes editoras. Pretendemos mostrar que o olhar de Ana C. sobre seus contemporâneos é já, desde o começo, defasado: ao mesmo tempo, participante e distanciado, consciente da institucionalização da geração e da sua dicção. Como diz com ironia numa bela carta de 14 de maio de 1976: "É engraçado estar participando ao vivo da 'história literária' (pretensão?)" (CÉSAR, 1999, p. 98).

\section{SURTO POÉTICO, SURTO CRÍTICO}

Já é comum apontar que, desde os primeiros anos da década de 1970, o circuito cultural brasileiro, principalmente carioca, assistiu ao surgimento do que se chamou de uma "revitalização da poesia". "Hoje, o artigo é poesia. Nos bares de moda, nas portas de teatro, nos lançamentos, livrinhos circulam e se esgotam com rapidez", resumia Heloisa Buarque de Hollanda no prólogo a 26 poetas hoje (2001, p. 9). Edições e lançamentos coletivos, na livraria Muro ou no Parque Lage, vendas em livrarias ou em mãos, matérias em revistas ou jornais, exposições, encontros em bares, leituras públicas, performances, as artimanhas da Nuvem Cigana, assim como programas de disciplinas universitárias eram testemunhos de um fenômeno que - no começo considerado um "surto de poesia" - percorreu a década toda. ${ }^{2}$ Segundo Carlos Alberto Messeder Pereira, já no começo dos 1970, o surto estava no ar e "se tornava visível na sucessão de artigos que, por esta época, foram publicados em jornais como Movimento,

\footnotetext{
$1 \mathrm{O}$ primeiro artigo que aparece publicado em um meio reconhecido foi "Os professores contra a parede" (Opinião) em 12 de dezembro de 1975, que consistia em um balanço, seguido de entrevistas, dos debates sobre a pertinência e a forma do ensino de teoria, principalmente o estruturalismo, nas universidades brasileiras.

2 Entre outros, formaram parte do "surto" os paradigmáticos livros Me segura que eu vou dar um troço (1971), de Wally Salomão; Preço da passagem (1972), de Chacal; Grupo escolar (1973), de Cacaso. No geral participavam de maleáveis coleções (PEREIRA, 1981, p. 283), ou eram editados por coletivos de autores, como - entre os mais importantes do Rio de Janeiro - Frenesi, de 1973, formado por Chico Alvim, Cacaso, Roberto Schwarz, João Carlos Pádua; o coletivo "multimídia” Nuvem Cigana, com Chacal, Charles, Guilherme Mandaro, entre outros; a coleção Vida de artista, a partir de 1974; ou Folha do rosto da mesma época.
} 
Opinião, GAM, Jornal do Brasil, e em revistas como Malasartes, Anima, José, Escrita, Veja, Isto é e até mesmo Fatos e fotos" (PEREIRA, 1981, p. 15).

Tais ressonâncias da produção literária em artigos da mídia nos permitem sublinhar o fato de que, além do surto na poesia, existia um surto na crítica do qual, veremos, Cacaso e Heloisa Buarque de Hollanda foram exemplos e, ao mesmo tempo, precoces analistas. Sabemos, através uma resenha deles aparecida alguns meses depois na revista Argumento, que foi em outubro de 1973 que se realizou na PUC-RJ um encontro chamado "Expoesia I". Segundo eles, o evento pretendia ser uma amostra da produção poética dos últimos tempos no Brasil: "levantar o que existe hoje” (BRITO; HOLLANDA, 1997, p. 55). 3 A exposição contava, entre os pilotis e o primeiro andar do prédio da Gávea, com conferências, debates, mesas redondas e a exibição de poemas-cartazes, poemas-evento, poemas mimeografados e poemas sem adjetivo. Representantes de diferentes linhagens: o concretismo, a geração 45 , a poesia práxis e a poesia processo, que vinham das décadas anteriores; e uma parte significativa desse "surto de poesia atual", que aparecera com o começo da década.

Mas nosso interesse, no entanto, volta-se para a aparição do próprio artigo, e não tanto para o evento que ele resenha, pois nele Heloisa e Cacaso encenam uma atitude sintomática. $\mathrm{O}$ artigo é uma dentre as várias tentativas, feitas no calor da hora, de encontrar características comuns para essa novíssima poesia que conseguissem fazer desse surto poético, uma geração ou, no mínimo, uma nova tendência, como se a crítica estivesse, embora negando-o de forma explícita, procurando um "programa". Mas ao mesmo tempo, os autores chamam a atenção - mesmo que não cheguem a fazer uma análise - sobre esse outro surto do qual eles mesmos seriam, ao mesmo tempo, participantes e críticos:

Está acontecendo um "surto de poesia" hoje no Brasil? Tal indagação tem ocupado ultimamente, e com tal insistência, a reflexão de jornalistas, professores, intelectuais, etc., que talvez já possamos até falar da existência de um novo surto, o "surto da indagação". Tudo isso no momento é muito sintomático (BRITO; HOLLANDA, 1997, p. 59).

A emergência de uma produção poética de forma não sistemática nem programática - o surto - era cercada, da primeira hora, com nomes e definições tentativamente aglutinadores. A simultaneidade

3 Publicado originalmente na revista Argumento, n. 3. Rio de Janeiro, janeiro 1974. 
dos processos, o de revitalização da poesia e o de reflexão sobre essa produção, permite pensar que a instância crítica de legitimação contribuiu de forma essencial à formação do objeto da "poesia 70 " e à sua precoce consagração, seu ingresso na "história literária", porém sem ingenuidade. Essa urgência de legitimação era uma urgência por contestar a ideia, surgida também nos primeiros anos da década de 1970, deque o Brasil estaria passando por um vazio cultural, termo utilizado por Zuenir Ventura no título do conhecido artigo publicado na revista Visão, em julho de 1971. Ventura descrevia ali certa crise da cultura brasileira daqueles anos, caracterizada não tanto pela ausência de produções, mas pela "quantidade suplantando a qualidade, o desaparecimento da temática polêmica e a controvérsia (...) a hegemonia de uma cultura de massa buscando apenas o consumo fácil" (GASPARI; HOLLANDA; VENTURA, 200o, p. 41), preocupações recorrentes na crítica cultural daquela época (e de todas, como mostra o insistente ressurgimento da queixa frente à "crise" da cultura, da literatura, ou da arte na mídia). Nesse sentido, tornar a nova poesia um movimento claro faria parte da procura de legitimação e de difusão de uma concepção de arte, de poesia e de cultura, que pudesse se contrapor à "perspectiva sombria" do vazio. Assim, mesmo cientes do caráter espontâneo e heterogêneo das manifestações, os críticos menos pessimistas parecem se esforçar por encontrar algum traço compartilhado entre os diferentes poetas, que solidifique um frente no que se apresentava como uma luta cultural, e para isso destacam o "contra quê": marginais ao circuito das grandes editoras, marginais a um sistema padronizado de produção, marginais ao mercado e à linguagem mercantilizada.

De certo modo, essa insistência na procura de uma definição nos deixa ver que o importante para essa crítica não era tanto a definição da geração (que tanta importância tomou depois), mas a luta na qual ela vinha se inscrever - kulturkampf, em termos gramscianos. Daqui que tampouco nos interesse agora fazer uma definição - se eram ou não eram marginais, se tinham ou não tinham uma dicção espontaneista -, senão mudar o foco do estudo dos campos culturais, o dessa e de outras épocas, já que eles se definem "mais pelo que excluem que pelo que aglutinam" (BOURDIEU, 1992, p. 69). Procurar ler, não as suas características elencáveis, mas o que eles não chegam a encenar, seus limites internos, seus não ditos, as suas posições não tomadas. 


\section{A INFORMALIDADE DO CONVÍVIO, A FORMALIDADE DE UMA ANTOLOGIA}

"O que os reúne, além da afinidade dos habitus, é a recusa anticonformista do conservatismo oficial", diz Bourdieu em As regras da arte (1992, p. 110), ao descrever o grupo dos primeiros realistas na França do século XIX. Desfiando a frase poderíamos dizer que, se para a crítica de intervenção o que reúne a geração é a sua política editorial marginal, para os poetas o que os move a se juntar seria principalmente a afinidade do habitus configurado, nesse caso, por práticas por vezes, e só por vezes, contrapostas àquelas condutas permitidas pelo Estado autoritário e ao convencionalismo da classe média.

Poesia e afinidades afetivas se mostram juntas na hora de analisar o surto poético dos 1970. Os poetas mantinham relações de amizade ou namoro, compartilhavam atividades culturais, lugares de lazer, salas de aulas, redações de jornais, sendo esses os lugares privilegiados de trocas entre escritores naqueles anos (MORICONI, 2006). Não apenas conviviam, também tinham muitas vezes biografias comuns em famílias de classe média da zona sul carioca. O exemplo sempre trazido para dar conta do convívio da geração são os encontros na fazenda de Lui. ${ }^{4}$ Uma propriedade da família de Luis Olavo Fontes, naquela época namorado de Ana Cristina, onde escritores, artistas plásticos, músicos e afins se reuniam. Diz Charles:

Era um maná, um pequeno Shangri-lá. Pequeno não, imenso. Na verdade era do avô dele, um milionário rei do cimento. E era uma figura curiosíssima, que adorava animais. Então ele transformou a fazenda num tipo de zoológico (Nuvem Cigana, 2007, p. 41).

Lugar onde produção de poesia e prazer se associam, como relata Cacaso:

Eu tinha um prazer enorme em fazer o poema, quer dizer, como tinha o convívio, não sei o quê... o bate papo (...) às vezes não era só poesia não, tinha

4 O sítio ganhou uma importância mitológica no livro de Carlos Alberto Pereira e proliferou em diferentes textos, como no Ana Cristina César, de Italo Moriconi, onde se lê: "O livro de Carlos Alberto colocou na história da vida literária carioca os 'fins de semana na fazenda do Lui' onde, entre baseados e descobertas do corpo, discutia-se literatura, metiase o malho nos professores, trocavam-se textos e literalmente produziam-se livrinhos de poesia, tendo a coleção Vida de artista saído de lá" (MORICONI, 1996, p. 6o). 
uns caras que desenhavam, uns caras que faziam música... todo mundo fazia essas coisas, não é? Então o convívio incentivou esse tipo de coisas também (apud PEREIRA, 1981, p. 285).

Esses encontros funcionavam, segundo Carlos Alberto Messeder Pereira, como instâncias de legitimação internas do grupo (PEREIRA, 1981, p. 286), mas Ana Cristina Cesar, que participava deles descreve com certa distância irônica essa legitimação: "as pessoas ficavam lá fazendo seus livrinhos e ficavam discutindo (...) e tinha assim toda uma roda de meninas em volta" (apud PEREIRA, 1981, p. 285).

Os poemas do convívio, esses frutos precariamente materiais da afetividade, achariam uma visibilidade maior no ano 1976, na antologia 26 poetas hoje, compilação encomendada pela editora Labor à Heloisa Buarque de Hollanda, que foi, poderíamos dizer, um divisor de águas para a poesia de 1970. Depois da aparição da antologia, rapidamente se deflagraram intensos debates, principalmente em revistas de cultura, em torno da plausibilidade de definir o grupo de poetas que ali aparecia já como uma geração, e sobre se existia ou não alguma novidade, alguma inovação, na linguagem desses jovens poetas. Jorge Wanderley, por exemplo, fala - não sem sarcasmo - de um "aparecimento momentoso", na apresentação do debate aparecido no segundo número da revista José, do qual participaram Heloisa Buarque, Geraldo Carneiro, Eudoro Augusto, Ana Cristina e os editores da revista, o próprio Walderley, Luiz Costa Lima e Sebastião Uchoa Leite, representantes das antípodas da poesia marginal em termos estéticos.

A publicação, que tem sido objeto de resenhas favoráveis, resenhas neutras e resenhas desfavoráveis, é assunto para muito debate e muita discussão, pelo que o éter anda cheio de argumentos e poetas e leitores se atropelam com as sílabas dos versos desta talvez nova poesia Brasileira (José, 1976, p. 3).

Mas as discussões acirradas e questionamentos, longe de minimizar o impacto da antologia 26 poetas hoje, deram mais força e visibilidade ao proposto na introdução de Heloisa Buarque, onde se apontavam algumas características dessa poética que funcionariam como estaca zero para os estudos posteriores: que a poesia que ali aparecia estava marcada pela "desierarquização do espaço nobre da poesia", "a subversão dos padrões literários dominantes”, as referências ao momento político, a linguagem coloquial, e a tentativa de unificar poesia e vida (HOLLANDA, 2001, p. 10). Em um olhar retrospectivo, então, a antologia parece funcionar como uma 
primeira versão para historiografia literária, uma versão "inaugural”. E Heloisa Buarque de Hollanda, quem definiu (mesmo sem querer, mesmo montando a antologia como uma estratégia de luta e não de definições) os parâmetros de leitura da poesia do grupo.

Assim, paradoxalmente, 26 poetas hoje dava visibilidade e lançava as bases da construção de uma "geração", a partir da institucionalização daquilo que tinha na não institucionalização sua característica mais preciosa. O "surto" se detinha, ou esgotava, e passava a ser avaliado por linguagens institucionalizadas, ainda que elas mesmas estivessem tentando reformar-se, e desse modo interagia com o contexto políticosocial participando da gradual abertura política e a absorção, pelo mercado e pela academia, dos comportamentos "desbundados". Isto combinado com uma perda de efervescência nas atitudes de distribuição dos próprios poetas e na força de aglutinação: já no final da década de 1970, começam a se dispersar os núcleos mais ativos dos coletivos de edição e o da Nuvem Cigana. Como se a proposta da antologia chegasse para tornar visível uma cisão latente, e uma necessidade de reposicionamento, como explica Charles relatando a reação frente ao convite para a antologia: "Ficou aquela conversa, se participávamos ou não, porque era uma coletânea oficial, com editora comercial e tudo. No fim, todo mundo topou, menos o Ronaldo Santos" (Nuvem Cigana, 2007, p. 101). Em outras palavras, em 1976, os poetas marginais da primeira hora, os que tinham começado a produzir no final da década anterior - Ana Cristina César começa a produzir poucos, mas significativos, anos depois - achavam-se em um impasse, marcado por necessidades pessoais e familiares - casamentos, filhos -, sinais para eles muito claros do esgotamento de um modo de comportamento que já não funcionava como oposição ao status quo. ${ }^{5}$ Para continuar escrevendo era preciso (re)signar, mudar os signos da colocação no campo. O campo tinha mudado, já não havia viagens à fazenda.

\section{DANÇA COMIGO, COMO SE DANÇA NA TRIBO}

Não sou personagem do seu livro e nem que você queira não me recorta no horizonte teórico da década passada.

Ana Cristina César, de "Inverno Europeu”

5 Diz Charles, se referindo aos anos da virada da década: "Quando a gente caiu em si, já estávamos em outra realidade, trabalhando em empregos convencionais" (Nuvem Cigana, 2007, p. 139). 
Se a antologia foi uma espécie de primeira versão da história literária, a segunda, certamente, foi Retrato de época. De fato, no ano de 1978, quando a experiência da geração marginal ainda não era um capítulo fechado, mas já não mais uma novidade, Carlos Alberto Messeder Pereira, formado pelo Museu Nacional, decidiu dedicar sua pesquisa de mestrado em antropologia a essa tribo urbana de poetas. Como assinala a própria Ana Cristina numa resenha do livro, Pereira é "praticamente da mesma geração e do mesmo mundo que a 'tribo' sobre a qual ele faz foco neste livro: certos poetas 'marginais' atuantes no Rio na década de 70" (CESAR, 1981, p. 5). ${ }^{6}$

Publicado em 1981, Retrato de época foi o livro resultante dessa pesquisa. Desde o começo, o autor destaca que, embora seu objeto de análise seja um fenômeno literário, para os efeitos da pesquisa devia ser visto como um fenômeno cultural, que tinha "uma determinada maneira de pensar a literatura, a arte e a produção intelectual em geral" (PEREIRA, 1981, p. 12). O trabalho de campo antropológico faz com que o livro ganhe em entrevistas e dados factuais do cotidiano da vida literária, sem fazer uma análise textual ou tradicionalmente literária da boa quantidade dos textos ali apresentados. Assim, aparece uma outra chave para lera produção desses anos: não é suficiente fazer uma análise só do ponto de vista estético, é necessária uma perspectiva cultural. O livro de Pereira seria a clara manifestação da aparição de "uma dominante cultural e antropológica" no trabalho com literatura, tal como analisa Silviano Santiago em "A democratização no Brasil (1979-1981) Cultura versus arte" (2004, p. 134). Nesse artigo, Santiago levanta o principal problema do tipo de abordagem feito em Retrato de época: "O texto do poema passa a funcionar como um depoimento informativo e a pesquisa de campo é analisada como texto" (2004, p. 137), esvaziando e questionando o discurso poético naquilo que teria de específico. Porém, isso não negaria a necessidade de tentativas de leitura dos anos 1970 em que "a ousadia metodológica representa também uma ousadia geracional. O poema se desnuda dos seus valores intrínsecos para se tornar um mediador cultural" (SANTIAGO, 2004, p. 138).

Ana Cristina também aponta o risco:

6 Esta resenha, uma das mais interessantes escritas por Ana Cristina Cesar, publicada no Suplemento Leia, em 1981, não foi até agora reeditada - apesar das sucessivas edições, antologias e coletâneas organizadas da sua obra. 
Para quem mexe com literatura, a abordagem etnográfica pode provocar estranhamentos, mas uma coisa é certa: na leitura deste livro, lentamente vai se desenhando uma outra imagem do fenômeno que nós chamamos de literário, onde o que contam são os modos sociais de circulação do discurso e os comportamentos que definem ou respondem a essa circulação (CESAR, 1981, p. 6).

Ou seja, os poemas apresentados em Retrato de época não podem ser lidos apenas desde a especificidade da linguagem poética, porque perderiam sua principal fonte de interesse, mas tampouco podem ser lidos apenas como "informantes" do antropólogo. Não é a linguagem poética "o que conta”, mas os modos de circulação do bem simbólico no campo, e as mediações entre os produtores e o horizonte de público.

A resenha de Ana, significativamente intitulada "Contatos imediatos do terceiro grau” (1981), faz questão de chamar a atenção para um problema específico do olhar antropológico, quanto à forma de estudar o Outro. Enquanto resenhista, ela encena a recuperação de certo olhar distanciado, mas só para comprovar que esse modo se tornou impossível: "Por que será que a antropologia urbana ainda me dá um desconforto esquisito? Será apenas porque o antropólogo não vai para selva, e sem sair da sua cidade continua a olhar em volta à procura do Outro irredutível?” (CESAR, 1981, p. 5). Carlos Alberto faz parte da tribo que estuda e, para analisála, diz Ana, ele tem que inventar "metodologicamente uma inocência primordial”, um Outro radicalmente diferente, a ser descoberto. Mas o Outro não se esconde, nem a sua alteridade é radical, o antropólogo não vai até um lugar recôndito, mas até o sofá da casa de um amigo, daí que uma inocência primordial só seja possível se inventada.

No exemplar de Retrato de época que pertencia a Ana Cristina - e que se encontra no acervo do Instituto Moreira Salles -, pode-se ler uma nota manuscrita por ela na folha de rosto que reenvia - também como marca geracional - ao antropo-pop de Rita Lee, e diz: "Baila, baila comigo, como se baila na tribo". Novamente a ironia de se recusar a pertencer, mas também recusar o exotismo. Esse Outro são seus amigos e é ela mesma, e há uma relação tribal. A frase garatujada revela certa ironia frente ao apagamento desse tribalismo dos poetas na pesquisa de Pereira, da qual o próprio antropólogo se exclui - sai da dança, na qual estava -, para tingir a pesquisa de objetividade, isto é, institucionalizá-la. Para estudar parecia preciso parar de dançar, tirar um retrato, e pedir algumas identidades para tomar as impressões da viagem. 
Mas ainda falta um dado. Na resenha, Ana não menciona sua própria aparição como objeto do livro. Se a resenha faz parte do "interesse em estudaro seu própriouniverso”, própria dessa geração tãoautorreferenciada - como diz Heloisa Buarque comentando o livro de Pereira no Jornal do Brasil em agosto de 1981 (apud SANTIAGO, 2004, p. 138) -, que significado traz o ocultamento do próprio papel na resenha de Ana? Talvez seja mais uma marca, mal resolvida, da tensão entre a distância crítica e a participação no grupo que aparecia na ironia da referência aos encontros na fazenda. Talvez também porque no livro ela é trazida para funcionar como exceção, como o limite interno da tribo.

Em Retrato de época, além da particularidade da visão antropológica, me interessa ver qual o lugar que Carlos Pereira dá a Ana Cristina. A pesquisa é realizada antes dela ter publicado algum livro, apenas uns poemas avulsos em revistas e outros 26 poetas hoje. No entanto, Ana já teria um lugar diferenciado, dentro do grupo de novos poetas. O livro vai estudar diferentes grupos, principalmente a partir das suas iniciativas de "edição", quais sejam, Folha do rosto, Nuvem Cigana, Frenesi, e Vida de artista; mas entre esses grupos aparecem três autores chamados de "independentes". Tanto por sua posição no campo intelectual, quanto por sua trajetória" (PEREIRA, 1981, p. 182). São eles Eudoro Augusto, Afonso Henriques Neto e Ana Cristina Cesar.

Sobretudo desde a morte de Ana em 1983, a grande diferença comparativa assinalada pela crítica centrou-se nos seus textos: os poemas de Ana teriam mais densidade do ponto de vista estético. Estratégia crítica que Messeder Pereira já encenava, ensaiando um afastamento do seu método antropológico para analisar (mesmo que superficialmente) o trabalho com o poema desde um ponto de vista estético. Ele divide a produção de Ana em duas linhas (aliás, apontadas por ela própria): por um lado, uma série de poemas mais “torturados", de compreensão menos direta, e de outro, uma série de textos construídos como "montagens de coisas reais, 'brincadeiras' com a correspondência, biografias, diários (...) textos profundamente marcados pelos fatos e situações do dia-a-dia” (p. 222). Contudo, essa diferenciação também estaria, para o autor, na poesia de Luis Olavo Fontes, por exemplo.

Portanto, não seria essa a particularidade que faz de Ana Cristina uma dos "independentes", senão o fato de não pertencer oficialmente a nenhum dos coletivos analisados - sendo, inclusive, que Folha de rosto a convidara a publicar -, por dois motivos: "não querer se envolver com a 
questão da distribuição", motivo que fica sem efeito assim que Ana publica Cenas de abril, em 1979, em edição de autor, e "por discordar da ênfase do grupo na discussão sistemática dos textos de cada autor que comporiam a antologia; isto, na sua opinião, significava colocar-se na 'postura de poeta"' (p. 222). Apesar dessa negativa de participar oficialmente de um grupo, Ana declara que é justamente o convívio o que a levara a publicar: "Como a própria autora salienta, é animada por toda a movimentação em torno da poesia que ela tomou a iniciativa de publicar seus trabalhos" (p. 222).

Florencia Garramuño, entre outros críticos, chama a atenção para a necessidade de uma reavaliação - não negação - da colocação excepcional de Ana Cristina, analisando um pequeno poema, "A Lei do grupo" (CESAR apud SUSSEKIND, 1995, p. 17):

todos os meus amigos

estão fazendo poemas-bobagens

ou poemas-minuto

Diz Garramuño:

aunque es posible leer ese texto como una declaración de la diferencia de Ana C. con respecto a una poesía marginal con una economía del verso menos elaborada, el texto es, como toda la escritura de Ana C., engañoso. Por un lado, claro, está su diferencia frente a aquello que todos sus amigos están haciendo. Pero esa distancia, en todo caso -si es que es tal-, es relativa: quienes están haciendo poemas minuto son, precisamente, "todos os meus amigos" (...) lo cierto es que este mismo poema es un poema-minuto o poema-bobagem (GARRAMUÑO, 2003, p. 66).

Nesse sentido, longe de continuar pensando ela na sua excepcionalidade, devemos ler a singularidade da sua relação com a tradição poética. Como diz seu amigo e colega de faculdade, Italo Moriconi, no livro Ana Cristina Cesar: o sangue de uma poeta (1996): "Vamos ressituá-la como parte de uma geração. Geração intelectual, não apenas poética. Pois Ana manteve sempre uma relação reflexiva com sua própria poesia" (MORICONI, 1996, p. 13), e a dos seus amigos. A diferença que ela mantém, então, a respeito dos outros poetas não é apenas no trabalho com o poema, nem pela sua decisão de publicar ou não, mas uma distância na perspectiva crítica e num posicionamento conscientemente procurado dentro do campo, já que, como explica Bourdieu, as relações entre os integrantes do campo estão determinadas pelo habitus, "un producto de los condicionamientos, que tiende 
a reproducir la lógica objetiva de dichos condicionamientos, pero sometiéndola a una transformación" (BOURDIEU, 1990, p. 155). O campo de produção cultural se apresenta como um espaço de possibilidades de produção, determinadas por uma série de referências compartilhadas pelos integrantes do campo, embora não necessariamente por todos eles aceitas ou perpetuadas. Mas essa determinação, como foi muitas vezes criticado ao próprio Bourdieu, nunca é totalmente efetiva nem unidirecional: existe um grau de autonomia de cada agente na tomada de posição dentro do campo e em relação aos outros integrantes, ficando além ou aquém do que se considerava o horizonte de possibilidades.

\section{PROCURAS DE POSIÇÃO: UMA PERFORMANCE E O JORNAL BEIJO}

Tracemos, então, uma rede com alguns documentos do arquivo de Ana, que nos permitirá ver a posição sem ter posição marcada que ela construía e queria para si.

Em julho de 1976, teve lugar o lançamento da antologia 26 poetas hoje, no Parque Lage, "uma festa com microfone e palco", comenta Ana Cristina em uma carta a sua amiga Ana Cândida Perez:

Até subi no palco e li um trechinho de um ensaio do Mário que começa assim: "Nós modernistas de 22 não devemos servir de exemplo a ninguém". Me impressionou muito esse ensaio em que ele faz uma autoconfissão (que bobagem "autoconfissão" não é redundância?) (...) O Mário acaba por dizer que os modernistas pecaram por omissão política, que toda a obra dele é de um individualismo atroz (CI, p. 259).

Qual é o significado da leitura de Ana? Da eleição desse texto de Mário para ser lido no próprio lançamento da antologia que entroniza ao grupo de poetas como "nova geração"? À primeira vista, poderíamos dizer que a poesia marginal tem vários pontos de contato com a tradição do modernismo de 22: a utilização de temas do cotidiano, o humor, o poema-piada/minuto/bobagem, a dicção coloquial, a oposição ao discurso acadêmico e hegemônico que, no caso do modernismo, tinha sido proposta como "a atualização da inteligência artística brasileira" (ANDRADE, 1972, p. 250) e que, no caso dos poetas marginais, se exerceu principalmente, através de uma forma alternativa de circulação. Mas essa filiação nobre - que, segundo Heloisa Buarque acabou por ser um "desvio 
teórico de avaliação com o qual se perderam os melhores argumentos para valorizar a geração" (HOLLANDA, 1997, p. 345) - não parece ser o motivo central da escolha de leitura de Ana.

Ana traz justamente Mário, e não o Oswald de Andrade dos poemaspiada e Serafim Ponte Grande. Mário de Andrade definitivamente não fazia parte da possível genealogia literária modernista dos marginais. Como se a escolha de Ana viesse acentuar seu distanciamento em relação aos seus amigos, já eloquente se observarmos as fotos do evento publicadas no livro Nuvem Cigana (2007):

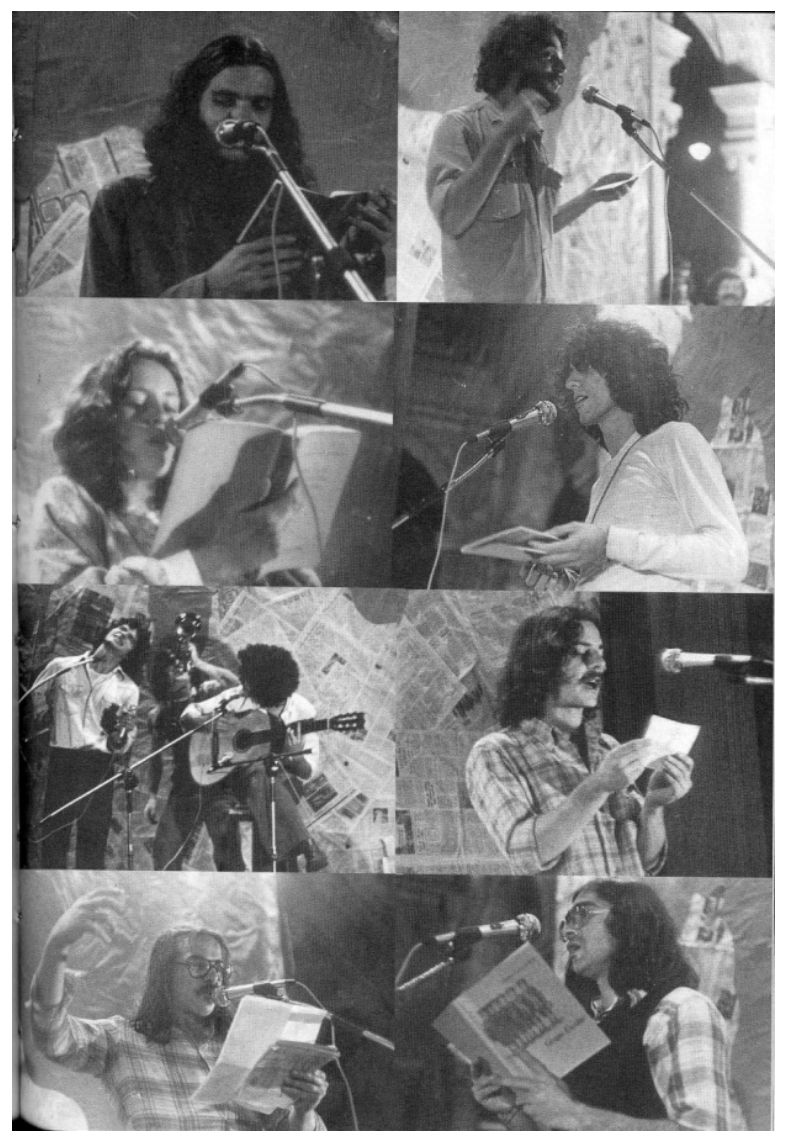

Da série de oitos fotos, Ana Cristina é a única mulher - dado não menor, embora não vamos nos aprofundar nesse ponto - e a única que tem um livro "grande" nas mãos. Bernardo Vilhena e Guilherme Mandaro empunham pequenos livrinhos; Cacaso lê do seu artesanal Grupo escolar; 
Charles, Ronaldo Santos e Roberto Piva apenas seguram umas folhas; Chacal nem lê, e se acompanha de um violonista. Ana, na contramão, segura -como sabemos pela carta - o grande volume de Mário de Andrade, numa pose de leitura típica de aluna aplicada. Ana é diferente, lê diferente e, carregando essa tensão, faz parte do grupo.

Mas voltemos ao Mário, pois ambos os movimentos, marginal e modernista, serão objeto de uma crítica similar por alguns de seus representantes: a atitude literária de ruptura implicou deixar de lado qualquer compromisso político. Essa é a autocrítica de Mário no balanço que realiza vinte anos depois da Semana, e essa parece ser a diferenciação que Ana Cristina lança através dele nessa apresentação do livro e da própria geração. Mas, se em Mário a distância temporal (20 anos depois da Semana) e o tom desencantado marcam um fechamento e uma impossibilidade de mudança, o fato de Ana Cristina, nesse lugar, nesse evento, fazer essa mesma crítica outorga uma possibilidade de projeção. De fato, o trecho escolhido por Ana continua umas linhas depois: "Se de algo pode valer meu desgosto, a insatisfação que me causo, que seja para que os demais não se sentem como eu à beira do caminho, a ver passar a multidão" (ANDRADE, 1972, p. 254). Seguir o conselho de Mário, isto é, a tentativa de evitar cair no que se pensava como descompromisso e individualismo, determinará a procura de posição de Ana C. no campo. Como diz Bourdieu, um autor "uma vez situado, não pode não se situar" (1997, p. 64), mas isso não nega a possibilidade da procura permanente de não se posicionar de forma definitiva. Nesse sentido, a procura de uma posição não marcada, sem definições panfletárias nem demasiado explícitas, dará aos textos de Ana formas em constante formação.

Um mês antes da apresentação no Lage, em junho de 1976, Ana Cristina diz em outra carta:

Estou descobrindo e amando o Benjamin. Devorei este fim de semana no sítio o Essais sur Bertold Brecht, que tem um ensaio fundamental, que me virou a cabeça - L'auteur comme producteur, conheces? (...) Fiquei também muito impressionada com a firmeza, a clareza política do Benjamin. Entrevi que a lucidez e a militância dão um sentido global às coisas que ele faz. (...) Eu nem me atrevo a encucar muito no assunto porque sei que a minha cabeça não comporta militância nenhuma no momento (CI, p. 114).

As cartas desse ano deixam aparecer certo conflito de Ana Cristina em relaçãoa sua "posição" comopoeta eintelectual. Noentanto, ocompromisso que ela estaria pedindo aos seus congêneres não é ingênuo, ela conhece 
bem as armadilhas do engajamento político, desconfia do movimento estudantil e do choque frontal contra as estruturas estabelecidas: "acho que existe uma certa ingenuidade de acreditar, por exemplo, que cuspir na estátua é um gesto de contestação a um regime mais amplo..." (José, 1976, p. 12), vislumbrando os próprios limites da opção marginal nesse momento.

Na correspondência de Ana C. aparecem as duas posições em disputa do campo cultural intelectual carioca da época: a necessidade de opor-se ao regime militar e de se comprometer com a luta estudantil; e o interesse por temas até então não considerados políticos, temas recusados, considerados produto da alienação do artista e do intelectual. Temas que Ana Cristina já vislumbra como política das relações, micropolíticas, que terão em seus escritos muito mais importância do que qualquer militância tradicional. Neste sentido, em maio de 1977, realiza-se no Rio uma das manifestações de maior importância para a política nacional dos estudantes, dado que representava o seu retorno às ruas (GASPARI et alii, 2000, p. 28), Ana Cristina participa da passeata, mas vai descrevêla de forma tal que a mudança do foco de interesse resulta mais do que evidente: "Eu estava na manifestação lá na PUC, 5.00o pessoas gritando 'o povo unido etc.' e de repente me ocorria ao peito que nada daquilo me interessava, eu queria um namorado para me enrolar” (CI, p. 146).

$\mathrm{O}$ interesse por questões até então consideradas alienadas, pequenoburguesas, ${ }^{7}$ decorre em paraleloà tomada de consciência dos dogmatismos autoritários de determinado setor da esquerda, e da limitação da justificação do valor de uma obra só por se colocar em oposição ideológica ao regime, ou por ser caçada pela censura. Em dezembro de 1976, Ana Cristina comenta em uma carta para Cecília Fonseca, de forma muito clara:

Há como que uma briga se articulando, digamos, nas esquerdas - de um lado a "frente ampla", (...) união contra o inimigo real do momento, vale tudo contra a ditadura, não vale falar mal nem criticar quem tá no mesmo saco. De outro lado (nem é um lado, estou sendo grossa, me entende, please) alguns grupos ou pessoas que não estão aceitando muito essa frente ampla e começam a criticar (...) Em princípio, acho que não dá essa frente ampla dogmática ("a censura é o mal do teatro atualmente” é uma das frases lapidares); porra, não é só a

7 Cf. Patrulhas ideológicas de Heloisa Buarque de Hollanda e Carlos Alberto Messeder Pereira (1980). 
censura; a censura vira desculpa, vira ponto de união de um saco de gatos onde entram inclusive os maiores filhos da puta (CI, pp. 136-7).

E, na mesma carta, comenta que está sendo articulado um novo projeto de publicação que tentaria se subtrair da camisa de força dessa frente ampla.

A partir dali, a procura de posição de Ana Cristina, em 1977, estenderá um novo fio: o Jornal Beijo, que teve sete números publicados entre novembro de 1977 e junho de $1978 .{ }^{8}$ Inicialmente, o jornal contava com uns quarenta editores, entre eles Cacaso, Silviano Santiago, Luiz Costa Lima, Julio Cesar Montenegro, Italo Moriconi, e vários membros do extinto Opinião, que tinha sido um dos principais veículos do debate cultural durante essa década, no entanto, o número diminuiu a quatro no último exemplar. Ana Cristina só figura como diretora, junto a essas muitas pessoas, nos três primeiros números, mas sabemos que renunciou ao projeto antes mesmo do primeiro número estar nas ruas.

No arquivo do IMS existe uma pasta com o nome "Dossiê Beijo", que contém 13 folhas. Uma delas apresenta um texto datilografado do que depois seria, com alguns acréscimos, o "Manifesto do jornal". Esse Manifesto, no entanto, não apareceu no jornal propriamente dito, mas circulava na folha para cadastramento de assinaturas que os editores apresentaram antes do lançamento do primeiro número com o fim de financiá-la ("Reconhecemos que o produtor é parte comprometida e interessada com o que produz. Por isso a nossa proposta é autogestão", diz numa das folhas). O jornal propunha uma nova forma de circulação dos textos, do conhecimento, e da imprensa cultural em geral. "A maioria queria fazer uma publicação que partisse da análise crítica dos circuitos do jornalismo cultural, da categoria dos intelectuais e de seu novo papel na relação com a sociedade" (MORICONI, 1996, p. 45).

Lê-se numa das páginas datilografadas que estão no arquivo:

Estamos com desejo de abrir um espaço que seja menos comprometido. (...) Fazer falar temas recalcados. A imprensa tem o monopólio velado de dizer que

8 No número 18 do Boletim de Pesquisa NELIC (2012), Maria Lucia de Barros Camargo publica o texto "Um Beijo para vocês: literatura e imprensa alternativa, anos 7o", que traz um precioso material sobre o jornal, com depoimentos do seu diretor Julio Cesar Montenegro, e também levanta a participação de Ana Cristina Cesar, inclusive percorrendo os seus comentários em cartas. $\mathrm{O}$ artigo foi publicado posteiormente à primeira redação deste texto. 
temas valem ou não. Vamos fazer isso sem velar. Não textos / nomes / objetos / espetáculos intocáveis. Os temas estabelecem compromissos (Dossiê Beijo).

Paradoxalmente, o primeiro chamamento por "compromisso" - o do Parque Lage com Mario de Andrade - encontra no projeto de Beijo uma resposta pelo "menos comprometido": menos comprometido com os temas avaliados pela imprensa de esquerda tradicional, mas também, ao mesmo tempo, um (re)compromisso com aqueles recusados pela dicção hegemônica dos jornais alternativos.

A realidadeéque são muitos, naquele momento, os jornaisalternativos que circulam com relativo sucesso, e o projeto do Jornal Beijo se dirige a esse mesmo público. Pergunta-se: "Por que mais um jornal? Pela necessidade de lutar contra a política cultural oficial e suas articulações” (Dossiê Beijo). O leitor interpelado seria aquele que compartilha as práticas alternativas de cultura, que - digamos - está condicionado pelo habitus, mas a proposta do Beijo estaria tentando exercer uma transformação dessas próprias condutas, a partir do modo de circulação e de relação entre as próprias matérias. Isto é, Beijo não propõe abertamente um fora; simplesmente propõe outros tipos de encontros dentro do campo de circulação do jornalismo cultural, contra o discurso paradoxalmente legitimado de oposição ao regime militar e à censura. Beijo tentaria se contrapor aos discursos que reagem aos discursos dominantes - mas que seriam tão autoritários quanto aqueles -, contra as definidas posteriormente como "patrulhas ideológicas", contra a "frente ampla", contra uma postura "maldita, marginal, herege" ingênua. ${ }^{9}$ "Entre a mão pesada que critico, a minha mão pesada, ironia grossa, didatismo, retórica de salário. (...) Quem domina quem? quem controla quem?” (CESAR, 1999, p. 211).

Isso implicava um abandono de uma concepção conteudística e pedagógica do jornalismo de esquerdas. Beijo declara no manifesto: "Não somos professor de leitor. Nem porta-voz do Bem Comum. E muito menos dos Interesses Nacionais”. Trata-se, então de desarticular, de dar lugar à emergência de outras vozes, que não sejam aquelas que achavam na imprensa um reflexo tranquilizador:

Para o grupo que compra Movimento, Opinião ou Versus e lê colunas de bom senso, lugares comuns a reiterar o próprio esquerdismo, praticantes enchendo

9 No primeiro número de Beijo, Ana publica seu conhecido artigo: "Malditos, marginais, hereges", onde faz uma pungente crítica à pose marginal. 
a pança e os ouvidos, exatamente o que eu esperava ouvir! (...) Desmitificação da frente ampla; da unidade das esquerdas (unidos desde que regrando o que seu mestre validar). Logo: possibilidade de emergência de contradições (especialmente as que a esquerda vem recalcando).// Essa emergência só se torna possível com estrutura de poder flexível, questionável, renovável. Desconcentração. Descentralização (Dossiê Beijo).

Beijo propõe a circulação, a permanente travessia dos discursos. $\mathrm{Ou}$ como escreve Ana num dos documentos ao tentar escolher o nome:

O nome: que não reflita nenhuma tendência liberal, nada abrindo nem se expandindo nem crescendo. Que não reflita a imprensa de ver e de mostrar (isto é, eis aqui, pois então, veja só). Nada de totalidades (povo, Brasil, nação) (...) Nada de títulos acadêmicos, referências eruditas. Nem pretensões libertárias. Nem pan-americanismos (Dossiê Beijo).

Uma circulação menos compromissada com a Política de maiúscula, e ao mesmo tempo mais corporal, sentimental, menor. O discurso circulando como um beijo. Em "Beijo e ambigüidade da sedução", de Rodrigo Naves, artigo que parece funcionar como editorial no primeiro número do jornal, ainda que nada o assinale, propõe:

Puxa vida! Só não se percebeu que a predisposição à sedução é uma das poucas formas onde se torna possível romper, ainda que momentaneamente, com uma existência alienada. (...) Seria interessante fazer um jornal que se deslocasse da posição de onipotência; seriam interessantes os leitores que deslocassem os jornais da sua posição de onipotência: o fim da polarização. (...) A tempo, a pergunta: beijemos-nos? (NAVES, 1977, p. 4).

O nome do jornal não apenas dá visibilidade, mas coloca em um lugar de máximo destaque temas banidos no jornalismo cultural, como a intimidade, a sedução e o erotismo, referidos na palavra "beijo". E nessa mesma palavra se catalisa uma nova proposta de relação, nem autoritária, nem onipotente, nem maniqueísta. Um tipo de relação táctil e dupla entre produtor e leitor, onde os limites quedariam diluídos na ambiguidade.

Afirma Ana Cristina num texto apresentado nas reuniões do grupo de editores:

8. Prática política e vida cotidiana: questionamento da distância ENTRE as propostas que norteiam a prática política e as relações cotidianas*.

* Ou: entre o afeto e a estratégia

Ou: entre "subjetivo" e "objetivo" 
Não é novidade para quem conhece a obra posterior de Ana C. Essa politização da intimidade será trabalhada em sua poesia desde o começo, como em "Jornal íntimo" publicado em 26 poetas hoje, onde se trabalha com o caráter público da escritura íntima, mas sempre sob a frase que parece definir o discurso de Ana Cristina: "não ter posição marcada”. Esse "Beijo" propõe, então, uma circulação lúbrica dos discursos e atuar em consequência. Consequência poética, que lemos em Inéditos de dispersos (p. 128):

discurso fluente como ato de amor incompatível com a tirania

do segredo

(...)

mas acontece que este é também o meu sintoma, "não

conseguir falar" =

não ter posição marcada, idéias, opiniões, fala

desvairada

Paradoxalmente, anos depois, a proposição se revelaria uma faca de dois gumes, pois naquela ideia de uma poética da circulação e da mobilidade, a crítica acharia uma definição incontestável, a posição marcada que a consagraria, posição que Ana C. programaticamente tentava evitar.

\section{REFERÊNCIAS BIBLIOGRÁFICAS}

ANDRADE, Mário de. O movimento modernista, Aspectos da literatura brasileira, São Paulo: Martins, 1972.

BENJAMIN, Walter. Charles Baudelaire. Um lírico no auge do capitalismo. Obras escolhidas vol. III (José Carlos Martins Barbosa. Hemerson Alves Baptista trad.). São Paulo: Editora Brasiliense, 1989.

BENJAMIN, Walter. O autor como produtor. Magia e técnica, arte e política. Ensaios sobre literatura e história da cultura. Obras escolhidas vol. I (Sergio Paulo Rouanet trad.). São Paulo: Editora Brasiliense, 1986.

BOURDIEU, Pierre. As regras da arte: gênese e estrutura do campo literário (trad. Maria Lucia Machado). São Paulo: Companhia das letras, 1992.

BOURDIEU, Pierre. Sociología y cultura (trad. Marta Pou). México: Grijalbo, 1990. 
BOURDIEU, Pierre. Para una ciencia de las obras. In: Razones prácticas. Sobre la teoría de la acción (trad. Thomas Kauf). Barcelona: Anagrama, 1997.

BRITO, Antônio Carlos de. (Cacaso). Não quero prosa. Rio de Janeiro: Editora da UFRJ, 1997.

BRITO, Antônio Carlos de; HOLLANDA, Heloisa Buarque de. Nosso verso de pé quebrado. In: Não quero prosa, Rio de Janeiro: Editora da UFRJ, 1997, pp. 53-65.

CESAR, Ana C. Dossiê Beijo, inédito - Arquivo Moreira Salles (1977).

CESAR, Ana Cristina. Contatos imediatos de $3^{\circ}$ grau (resenha de Retrato de época. Poesia marginal: anos 7o, de Carlos Alberto Messeder Pereira). Leia Livros, n. 37, São Paulo: 15 de julho/14 de ago.1981, pp. 5-6.

CESAR, Ana Cristina. A teus pés. São Paulo: Brasiliense, 1982. São Paulo: Ática / IMS, 1998.

CESAR, Ana Cristina. Inéditos e dispersos. (Armando Freitas Filho org.) São Paulo: Brasiliense, 1985.

CESAR, Ana Cristina. Crítica e tradução. (Armando Freitas Filho org.). São Paulo: Ática / IMS, 1999.

CESAR, Ana Cristina. Correspondência incompleta. (Orgs. Armando Freitas Filho e Heloisa Buarque de Hollanda). São Paulo: Aeroplano / IMS, 1999.

GARCÍA CANCLINI, Nestor. La sociología de la cultura en Pierre Bourdieu. In: BOURDIEU, Pierre. Sociología y cultura. México: Grijalbo, 1990.

GARRAMUÑO, Florencia; et alii (orgs.). Cuerpo, experiencia y subjetividades. Literatura brasileña contemporánea. Rosário: Beatriz Viterbo, 2007.

GARRAMUÑO, Florencia. Ana Cristina Cesar: Los secretos de la esfinge. Grumo, n. 2, Buenos Aires, nov. 2003.

GASPARI, Elio; HOLLANDA, Heloisa Buarque de; VENTURA, Zuenir. Cultura em trânsito: da repressão à abertura. Rio de Janeiro: Aeroplano, 2000.

HOLLANDA, Heloisa Buarque de. Impressões de viagem. CPC, vanguarda e desbunde: 1960/1970. Rio de Janeiro: Rocco, 1992.

HOLLANDA, Heloisa Buarque de. “Observações: críticas ou nostálgicas?”, Entrevista. 26 poetas ontem / 21 poetas hoje. Poesia sempre, Rio de Janeiro, ano 5, n. 8, junho 1997, pp. 343-347.

HOLLANDA, Heloisa Buarque de. (1976). Prólogo. 26 poetas hoje, Rio de Janeiro: Aeroplano, 2001.

HOLLANDA, Heloisa Buarque de. e PEREIRA, Carlos Alberto M. Patrulhas ideológicas. São Paulo: Brasiliense, 1980. 
HOLLANDA, Heloisa Buarque de. José. Literatura, crítica E arte. Rio de Janeiro, ano 1, n. 2, agosto 1976 .

MARQUARDT, Eduardo. Cultura em Opinião. As páginas de Tendências e Cultura (19721977), Dissertação de Mestrado. Universidade Federal de Santa Catarina. Disponível em http://www.cce.ufsc.br/ nelic/Dissert_Eduard/index_eduard.htm. Acessado em 25 de setembro 2007 .

MORICONI, Ítalo. Ana Cristina Cesar: O sangue de uma poeta. Rio de Janeiro: Relume Dumará: Prefeitura, 1996.

MORICONI, Ítalo. Circuitos culturais. Gragoatá. Revista de Literatura. Universidade Federal Fluminense, Niterói, n. 20, 2006.

Nuvem cigana - Poesia e Delírio no Rio dos Anos 70 (org. Sergio Cohn). Rio de Janeiro: Beco do Azougue, 2007.

PEDROSA, Celia. Poesia e experiência: anos 8o e depois. In: GARRAMUÑO, Florencia; et alii (orgs.). Cuerpo, experiencia y subjetividades. Literatura brasileña contemporánea. Rosario: Beatriz Viterbo, 2007.

PEREIRA, C. A. M. Retrato de época. Poesia Marginal. Anos 7o. Rio de Janeiro: Funarte, 1981.

SANTIAGO, Silviano. A democratização no Brasil (1979-1980). Cultura versus arte. In: $O$ cosmopolitismo do pobre. Crítica literária e crítica cultural. Belo Horizonte: Editora UFMG, 2004 .

SANTIAGO, Silviano. (1984). Singular e anônimo. In: Nas malhas da letra. São Paulo: Companhia das Letras, 1989.

SCHWARZ, Roberto. Cultura e política: 1964-69. In: O Pai de Família e outros ensaios. Rio de Janeiro: Paz e Terra, 1978.

SÜSSEKIND, Flora. Literatura e vida literária: polêmicas, diários E retratos. Rio de Janeiro: Jorge Zahar, 1985.

SÜSSEKIND, Flora. Até segunda ordem não me risque nada. Rio de Janeiro: Sette letras, 1995. 